\title{
EFEKTIVITAS PENERAPAN EXPERIENTIAL LEARNING BERBASIS BERPIKIR KRITIS DAN PENDIDIKAN KARAKTER PADA MATERI PERAKITAN KOMPUTER DI SMK N 2 BANGKALAN
}

\author{
Puji Rahayu Ningsih ${ }^{1}$, Etistika Yuni Wijaya ${ }^{2}$ \\ ${ }^{1}$ Jurusan Pendidikan Informatika \\ Universitas Trunojoyo Madura \\ Madura, Indonesia \\ puji.ningsih@trunojoyo.ac.id
}

\begin{abstract}
Abstrak
Tujuan penelitian ini adalah untuk mengetahui efektivitas penerapan Experiential learning berbasis berpikir kritis dan pendidikan karakter pada materi perakitan computer di SMK Negeri 2 Bangkalan. Pendekatatan penelitian ini menggunakan pendekatan kuantitatif dengan metode penelitian experiment. Desan yang digunakan adalah quasi experimental design dengan bentuk nonequivalent control group design Populasi dalam penelitian ini adalah seluruh siswa Tehnik Komputer jaringan (TKJ) kelas X di SMK N 2 Bangkalan, dan sampel yang digunakan adalah X TKJ 1 dan 2. Metode pengumpulan data yang digunakan meliputi observasi (aktivitas guru dan siswa), tes hasil belajar, dan angket. Berdasarkan hasil penelitian dan pembahasan, maka dapat disimpulkan bahwa penerapan Experiential learning berbasis berpikir kritis dan pendidikan karakter pada perakitan komputer di SMK $\mathrm{N} 2$ Bangkalan efektif, dikarenakan terdapat empat indicator efektivitas pembelajaran telah terpenuhi meliputi:1). Aktivitas guru memperoleh rata-rata 104,5 atau 99,5\% dan masuk kategori "sangat baik". 2) Aktivitas siswa memperoleh rata-rata 783,5atau 85,16\% dan masuk kategori "sangat baik". 3) Hasil belajar siswa, berdasarkan hasil perhitungan uji signifikan data yang diperoleh dari nilai pretest dan posttest kelas experiment $t_{\text {hitung }}$ sebesar 4,378 dan $t_{\text {tabel }}$ sebesar 2,080 dengan taraf signifikan 0,05. Karena $t_{\text {hitung }}>t_{\text {tabel }}$ maka $H_{o}$ ditolak dan $\mathrm{H}_{\mathrm{a}}$ diterima.jadi dapat disimpulkan bahwa terdapat pengaruh yang signifikan sebelum dan setelah pembelajaran dengan penerapan model Experiential learning berbasis berpikir kritis dan pendidikan karakter; dan 4). Respon siswa yang diperoleh setelah proses pembelajaran adalah 793 atau $91,15 \%$ dan termasuk kategori sangat setujuh.
\end{abstract}

Keywords: Experiential learning, efektivitas, pe rakitan komputer. 


\begin{abstract}
The practical purpose of this research is determining the effectiveness of the application of Experiential learning based on critical thinking and character education on computer assembly at Vocational High School 2 Bangkalan. This research used a quantitative method, with quasi-experimental a nonequivalent control group design. Population in this study was all students of Computer Network Engineering (TKJ) class X in Vocational High School 2 Bangkalan, and the sample used was X TKJ 1 and 2. Data collection methods used observation forms (teacher and student activities), learning achievement test, and questionnaire. Based on the results, we concluded that the application of Experiential learning based on critical thinking and character education was effective, because there were four indicators of learning effectiveness that: 1) Teacher activities gained an average of 104.5 or $99.5 \%$ and were categorized as "very good"; 2) Student activities get an average of 783.5 or $85.16 \%$ and were cate gorized as "very good"; 3) Student learning outcomes, based on the results of the calculation of significant test data obtained from the pretest and posttest value of the experimental class $t_{\text {count }}$ of 2.364 and $t_{\text {table }}$ of 2.080 with a significance level of 0.05 . Because $t_{\text {count }}>t_{\text {table, }} H_{o}$ is rejected and $H_{a}$ is accepted, so there was a significant influence before and after learning by applying Experiential learning models based on critical thinking and character education, and 4). Student responses obtained after the learning process was 793 or $91.15 \%$ and included in the category of strongly agree.
\end{abstract}

Keywords: Experiential learning, effectiveness, computer assembly 


\section{PENDAHULUAN}

\section{Teknologi} semakin berkembang pesat, semua informasi dengan mudah didapatkan. Namun terlepas dari semua itu, manusia harus mampu memilah dan memilih informasi yang tepat dan valid/bukan hoax. Kemampuan-kemampuan tersebut merupakan karakteristik dari berpikir kritis.

Pengembangan kemampuan berpikir kritis sekarang mendapat perhatian yang serius di setiap pembelajaran. Diulas dalam jendela Pendidikan dan Kebudayaan Edisi III (2016) yang menyatakan bahwa perbaikan kurikulum 2013 salah satunya adalah kemampuan siswa tidak dibatasi taksonomi proses berpikir, dan siswa diajak kembangkan kemampuan berpikir kritis mulai sejak dini.

Selain menitik beratkan kepada kemampuan berpikir kritis, peneliti juga mempertimbangkan terkait penanaman pendidikan karakter kepada siswa. Hal tersebut dilatarbelakangi karena banyak kejadian - kejadian yang tidak sepantasnya terjadi di dunia pendidikan, salah satu contonya adalah penganiayaan berujung maut yang dilakukan seorang murid SMAN 1 Torjum, HI (17) kepada gurunya Ahmad Budi Cahyono (26) (http://regional.kompas.com, diakses 4 april 2019). Dari kejadian tersebut, nampak bahwa siswa mengalami penurunan moral sehingga perlu penanaman pendidikan karakter dalam setiap pembelajaran yang mana diharapkan mampu memperbaiki moral anak bangsa. Hal tersebut sejalan dengan pesan Menteri Pendidikan dan kebudayaan (Mendikbud) Muhadjir Effendy yang mengatakan bahwa pendidikan karakter merupakan fondasi dan ruh utama pendidikan yang mendorong pendidikan nasional kembali memperhatikan olah hati (etik dan spiritual), olah rasa (estetik), dan juga olah raga (kinestetik) https://jendela.kemdikbud.go.id/home Idownloadfile/?name=EDISI_3_2016 .$p d f$. (Diakses 2 April 2019, pukul 13.57).

Berdasarkan hasil wawancara dengan guru produktif di SMK N 2 Bangkalan, sekolah tersebut telah menerapkan kurikulum Kurikulum 2013 versi revisi yang dalam pelaksanaanya juga memperhatikan aspek berpikir kritis dan pendidikan karakter. Sejauh ini di SMK tersebut telah menerapkan strategi tutor sebaya, yaitu siswa yang pandai mengajari siswa yang belum mampu secara kognitif, dan sekolah tersebut juga sudah mengenal model problem Base learning (pembelajaran berbasis masalah) yang mana guru memberi poin penting saja ke siswa dan siswa mencari sendiri. Penerapan beberapa model tersebut cukup berhasil namun pihak sekolah masih membutuhkan referensi lain terkait model lain yang sesuai dengan tuntutan kurikulum 2013 versi revisi.

Pada penelitian ini peneliti menerapkan model Experiential learning berbasis berpikir kritis dan 
pendidikan karakter yang memiliki tujuan tidak hanya membuat siswa mengasah berpikir kritis namun juga untuk menguatakan pendidikan karakter siswa. Pemilihan model tersebut sejalan dengan penelitain Nurhasanah, Malik dan Mulhadayatiah (2017) yang menyimpulkan bahwa terdapat peningkatan keterampilan berpikir kritis siswa dengan menggunakan model Experiential learning pada materi fluida statis. Hal tersebut juga diperkuat dari hasil penelitian Handaka, dkk (2016) yang menyatakan bahwa Experiential learning sebagai sebuah metode pembelajaran yang mengutamakan pengalaman sebagai sumber belajar yang dapat meningkatkan keterampilan berpikir kritis.

\section{METODE PENELITIAN}

Pendekatatan penelitian ini menggunakan pendekatan kuantitatif dengan metode penelitian experimen. Desan yang digunakan adalah quasi experimental design dengan bentuk nonequivalent control group design (Sugiyono, 2015). Penelitian ini dilakukan di SMK N 2 Bangkalan. Populasi dalam penelitian ini adalah seluruh siswa Tehnik Komputer jaringan (TKJ) kelas X di SMK N 2 Bangkalan. Pengambilan sampel menggunakan nonprobility sampling dengan jenis sampel jenuh. Sampel yang digunakan adalah X TKJ 1 dan 2. Metode pengumpulan data yang digunakan meliputi observasi (aktivitas guru dan siswa), tes hasil belajar, dan angket.

\section{HASIL PENELITIAN DAN PEMBAHASAN}

Penelitian dilaksanakan di SMK Negeri 2 Bangkalan pada kelas $\mathrm{X}$ Tehnik Komputer jaringan (TKJ) 1 dan 2 pada materi perakitan komputer. Penelitian dilakukan pada bulan agustus 2019. Adapun hasil penelitian meliputi data hasil observasi aktivitas guru, data hasil observasi aktivitas siswa, data hasil belajar siswa prestest dan posttest, dan hasil angket respon siswa.

\section{Data Hasil Observasi Aktivitas Guru}

Berdasarkan hasil observasi aktivitas guru diperoleh tabel berikut.

Tabel 1. Hasil observasi aktivitas

\begin{tabular}{llll}
\hline Keterangan & $\begin{array}{l}\text { Perte } \\
\text { muan } \\
\text { ke 1 }\end{array}$ & $\begin{array}{l}\text { Perte } \\
\text { muan } \\
\text { ke 2 }\end{array}$ & $\begin{array}{l}\text { Rata- } \\
\text { rata }\end{array}$ \\
\hline Skor & 104 & 105 & 104,5 \\
$\begin{array}{l}\text { Skor } \\
\text { maksimal }\end{array}$ & 105 & 105 & 105 \\
Persentase & $99 \%$ & $100 \%$ & $99,5 \%$ \\
\hline
\end{tabular}

Pada Tabel 1 menunjukkan bahwa aktivitas guru dalam menerapkan perencanaan pembelajaran memperoleh skor 104 atau 99\% pada kategori "sangat baik", begitu juga untuk pelaksanaan pembelajaran pada pertemuan kedua aktivitas guru memperoleh skor 105 atau $100 \%$ dan masuk kategori 
"sangat baik". Dari kedua pertemuan tersebut diperoleh rata-rata aktivitas guru selama pembelajaran adalah 104,5 atau $99,5 \%$ dan masuk kategori "sangat baik".

\section{Data Hasil Observasi Aktivitas} Siswa

Berikut data yang diperoleh yang ditunjukkan pada Tabel 2 .

Tabel 2. Hasil observasi aktivitas

\begin{tabular}{llll}
\hline Keterangan & $\begin{array}{l}\text { Perte } \\
\text { muan } \\
\text { ke 1 }\end{array}$ & $\begin{array}{l}\text { Perte } \\
\text { muan } \\
\text { ke 2 }\end{array}$ & $\begin{array}{l}\text { Rata- } \\
\text { rata }\end{array}$ \\
\hline Skor total & 750 & 817 & 783,5 \\
Persentase & $81,5 \%$ & $88,8 \%$ & $85,16 \%$
\end{tabular}

Berdasarkan tabel 2, menunjukkan bahwa aktivitas siswa selama proses pembelajaran pada pertemuan satu didapat skor 750 atau $81,5 \%$ pada kategori "sangat baik", begitu juga untuk pertemuan ke 2 didapat skor 817 atau $88,8 \%$ dan masuk kategori "sangat baik". Dari kedua pertemuan tersebut diperoleh rata-rata aktivitas siswa selama pembelajaran adalah 783,5atau $85,16 \%$ dan masuk kategori "sangat baik".

\section{Data Hasil Belajar Siswa}

Berdasarkan hasil perhitungan uji signifikan data yang diperoleh dari nilai pretest dan posttest kelas experiment $\mathrm{t}_{\text {hitung }}$ sebesar 4,378 dan $\mathrm{t}_{\text {tabel }}$ sebesar 2,080 dengan taraf signifikan 0,05 . Karena $t_{\text {hitung }}>t_{\text {tabel }}$ maka $\mathrm{H}_{\mathrm{o}}$ ditolak dan $\mathrm{H}_{\mathrm{a}}$ diterima.jadi dapat disimpulkan bahwa terdapat pengaruh yang signifikan sebelum dan setelah pembelajaran dengan penerapan model Experiential learning berbasis berpikir kritis dan pendidikan karakter.

\section{Data hasil Angket Respon Siswa}

Berdasarkan hasil angket respon sisw a diperoleh tabel berikut.

Tabel 3. Hasil Angket Respon Siswa

\begin{tabular}{cccc}
\hline $\begin{array}{l}\text { Skor } \\
\text { Total }\end{array}$ & $\begin{array}{l}\text { Skor } \\
\text { Maksi } \\
\text { mal }\end{array}$ & $\begin{array}{l}\text { Persen } \\
\text { tase }\end{array}$ & Kategori \\
\hline $\mathbf{7 9 3}$ & 870 & 91, & $\begin{array}{l}\text { Sangat } \\
\text { setujuh }\end{array}$ \\
\hline & & $15 \%$ \\
\hline
\end{tabular}

Berdasarkan Tabel 3 angket respon siswa, diperoleh skor total hasil angket adalah 793 atau 91,15\% dan termasuk kategori sangat setujuh.

\section{Pembahasan}

Pada penelitian ini penetapan efektivitas pembelajaran terdapat empat indikator antara lain: 1) aktivitas guru; 2) aktivitas siswa; 3) hasil belajar siswa (dikatakan efektif jika menunjukkan perbedaan yang siginifikan antara pemahaman sebelum dan setelah pembelajaran); dan 4) respon siswa dalam proses pembelajaran.

Untuk indikator pertama telah terpenuhi, hal itu nampak dari ratarata aktivitas guru selama pembelajaran adalah 104,5 atau $99,5 \%$ dan masuk kategori "sangat baik". Indikator kedua juga terpenuhi, hal itu nampak dari rata-rata aktivitas siswa selama pembelajaran adalah 
783,5 atau $85,16 \%$ dan masuk kategori "sangat baik". Indikator ketiga juga terpenuhi, hal tersebut nampak dari perhitungan uji signifikan data yang diperoleh dari nilai pretest dan posttest kelas experiment $t_{\text {hitung }}$ sebesar 4,378 dan $t_{\text {tabel }}$ sebesar 2,080 dengan taraf signifikan 0,05. Karena $t_{\text {hitung }}>t_{\text {tabel }}$ maka $\mathrm{H}_{\mathrm{o}}$ ditolak dan $\mathrm{H}_{\mathrm{a}}$ diterima.jadi dapat disimpulkan bahwa terdapat pengaruh yang signifikan sebelum dan setelah pembelajaran, serta indicator keempat juga terpenuhi yang nampak dari skor total hasil angket adalah 793 atau $91,15 \%$ dan termasuk kategori sangat setujuh.

\section{KESIMPULAN DAN SARAN}

\section{Kesimpulan}

Berdasarkan hasil penelitian dan pembahasan, maka dapat disimpulkan bahwa model experiential learning berbasis berpikir kritis dan pendidikan karakter pada perakitan komputer di SMK N 2 Bangkalan efektif, dikarenakan terdapat empat indikator efektivitas pembelajaran telah terpenuhi meliputi:

1. Aktivitas guru pada penerapaan model Experiential learning berbasis berpikir kritis dan pendidikan karakter memperoleh rata-rata 104,5 atau $99,5 \%$ dan masuk kategori "sangat baik".

2. Aktivitas siswa pada penerapaan model experiential learning berbasis berpikir kritis dan pendidikan karakter memperoleh rata-rata 783,5 atau $85,16 \%$ dan masuk kategori "sangat baik".

3. Hasil belajar siswa, berdasarkan hasil perhitungan uji signifikan data yang diperoleh dari nilai pretest dan posttest kelas experiment $t_{\text {hitung }}$ sebesar 4,378 dan $t_{\text {tabel }}$ sebesar 2,080 dengan taraf signifikan 0,05. Karena $t_{\text {hitung }}$ $>\mathrm{t}_{\text {tabel }}$ maka $\mathrm{H}_{\mathrm{o}}$ ditolak dan $\mathrm{H}_{\mathrm{a}}$ diterima.jadi dapat disimpulkan bahwa terdapat pengaruh yang signifikan sebelum dan setelah pembelajaran dengan penerapan model experiential learning berbasis berpikir kritis dan pendidikan karakter.

4. Respon siswa yang diperoleh setelah proses pembelajaran diperoleh skor total hasil angket yang disebarkan kepada siswa kelas experimen adalah 793 atau 91,15\% dan termasuk kategori sangat setujuh.

\section{Saran}

1. Model pembelajaran experiential learning berbasis berpikir kritis dan pendidikan karakter pada materi perakitan dapat digunakan untuk aplikasi materi lainnya yang sejenis.

2. Penelitian selanjutnya dapat mengkombinasi model experiential learning berbasis berpikir kritis dan pendidikan karakter pada materi perakitan dengan strategi/metode yang mendukung. 


\section{DAFTAR PUSTAKA}

Achmad, Arief. 2007. Memahami Berpikir Kritis. Tersedia di http://researchengines.com/1007arief3. html (artikel

pendidikan)(artikel

pendidikan). Diakses Tanggal 2 april 2019.

Fathurrohman, Muhammad. 2015. Model-Model Pembelajaran Inovatif. Yogyakarta: Ar-Ruzz Media

Filsaime, Dennis K. 2008. Menguak Rahasia Berpikir Kritis dan Kreatif. Jakarta: Prestasi Pustakaraya.

Fisher, Alec. 2001. Critical thinking. Cambridge: Cambridge University Press.

Fisher, Alec. 2008. Berpikir Kritis Sebuah Pengantar. Jakarta: Erlangga.

Handaka, dkk. 2016. Pemanfaatan Metode Experiential Learning untuk Meningkatkan Keterampilan Berpikir Kritis Siswa dalam Belajar. Prosiding Seminar Nasional "Optimalisasi Active Learning dan Character Building dalam Meningkatkan Daya Saing Bangsa di Era Masyarakat Ekonimi Asean (MEA)": 157-
164. Yogyakarta. 20 Maret 2016: Prodi PGSD dan BK FKIP UAD.

Herminarto Sofyan. 2008. Pengembangan soft skills dan pembelajarannya. Makalah disajikan dalam Seminar Mencetak Guru Profesional dan Kreatif Bidang Vokasi, di Jurusan PTBB Fakultas Teknik Universitas Negeri Yogyakarta

Kementrian Pendidikan dan Kebudayaan.

Infografis Gerakan Penguatan Pendidikan Karakter (PPK). https://www.kemendikbud.go.id /main/files/download/7bdf2592 741007e. (diakses 10 Agustus 2019)

Kementrian Pendidikan Nasional. 2010. Pengembangan Pendidikan Budaya dan Karakter Bangsa - Pedoman Sekolah. Jakarta: Kementrian Pendidikan Nasional Badan Penelitian dan Pengembangan Pusat Kurikulum dan Perbukuan.

Kementrian Pendidikan Nasional. 2010b. Buku Induk Pembangunan Karakter. Jakarta: Kementrian Pendidikan Nasional Badan Penelitian dan Pengembangan Pusat Kurikulum dan Perbukuan. 
Kementrian Pendidikan Nasional. 2011. Panduan Pelaksannaan

Pendidikan Karakter. Jakarta: Kementrian Pendidikan Nasional Badan Penelitian dan Pengembangan Pusat Kurikulum dan Perbukuan.

Kesuma, D., Triatna, C., Permana, J. 2012. Pendidikan Karakter: Kajian Teori dan Praktik di Sekolah. Bandung: PT Remaja Rosdakarya

Khabibah, Siti. 2006. Pengembangan Model Pembelajaran Matematika dengan Soal Terbuka untuk Meningkatkan Kreativitas Siswa Sekolah DasarI. Disertasi. Tidak Dipublikasikan. Surabaya: Universitas Negeri Surabaya.

Kolb, David A. 1984. Experiential Learning: Experience as The Source of Learning and Development. Newyork: Prentice Hall

Mustaqim, burhan dan Ary Astuty. 2008. Matematika untuk SD dan MI Kelas IV. Jakarta: Depdiknas.

Neff, Thomas J \& Citrin, James M. 1999. Lessons from the Top: In Search of America's Best Business Leaders. English: Crown Business
Nuhasanah, S, Adam malik dan D.Mulhayatiah. 2017. Penerapan Model Experiential Learning untuk Meningkatkan Ketrampilan Berpikir Kritis Siswa. Jurnal Wahana Pendidikan Fisika Vol.2 No.2: 58-62.

Rochmad. 2012. Desain Model Pengembangan Perangkat Pembelajaran Matematika. Jurnal KreanoVol.3 No.1: 5972

Samani, muchlas dan Hariyanto. 2012. Konsep dan Model Pendidikan Karakter. Bandung: Remaja Rosda Karya

Taufiqurrahman. 2018. Penganiayaan Guru oleh Siswa di Sampang.https://regional.komp as.com, (diakses 4 april 2019)

Tim Bina Matematika. 2007. Matematika Kelas Sekolah Dasar. Bogor:Yudhistira.

Trilling, Bernie and Charles, Fadel. 2009. 21st Century Skills, Learning for Life in Our Times.San Francisco:Jossey Bass

Wardani, Ningsih \& Saputro. 2017. Profil Berpikir Kritis Siswa Kelas X TKJ Ditinjau dari Kemampuan Awal Siswa Materi Struktur Kontrol 
Percabangan di SMKN 3

Bangkalan. Edutic Vol 4 No.1

Wijaya, cece. 2007. Pendidikan Remidial Sarana Pengembangan Mutu Sumber Daya Manusia. Bandung:Remaja Rosdakarya.

___ 2016. Empat Perbaikan Kurikulum 2013. https://jendela.kemdikbud.go.id /homeldownloadfilel?name =E DISI_3_2016.pdf. (Diakses 2 April 2019, pukul 13.57) 